\title{
INTRODUKSI FORMULA PUPUK HAYATI BERBAHAN AKTIF PSEUDOMONAD FLUORESCENT ISOLAT PF-122 UNTUK MENINGKATKAN PERTUMBUHAN DAN PRODUKSI TANAMAN CABAI DI LAPANG
}

\author{
Yenny Wuryandari, Sri Wiyatiningsih, \& Maroeto \\ Jurusan Agroteknologi, Fakultas Pertanian, UPN “Veteran” Jawa Timur \\ J1. Raya Rungkut Madya, Gunung Anyar, Surabaya, Jawa Timur 60294 \\ E-mail: yennyupn@yahoo.com
}

\begin{abstract}
Introduction of biofertilizer containing pseudomonad fluorescent isolate Pf-122 as active ingredient for improving growth and production of chili plant in the field. Some biological control agents required an efficient formulation required to be apply on large scale in the field. The purpose of this research is to review some biofertilizer formulations form of active ingredients pseudomonad fluorescent Pf-122 which can increase growth and production chilli in the field. The research using Randomized Complete Block Design (RCBD) which consists three kinds of formulation. The formulations are powder, granules and pellets. Chilli without formulations as a control. The best results was growth and production of chilli can be showed from plant height, branch number, productive branch number, fruit number, and fruit weight which was given powder formulation. The results of fruit number, the powder formulation which is given can produce double chilli yield than yield from control plant. Moreover, weight fruit from chilli which is given powder formulation can produce fourfold yields. Growth and production chilli which is given others formulations such as granules and pellets were not significantly different results. The overall result of this research, the best formulation to increase growth and production of chilli in the field was formulations contain active biopesticide pseudomonad fluorescent Pf-122 in powder.
\end{abstract}

Key words: granules, pellets, powder, pseudomonads fluorescent

\section{ABSTRAK}

Introduksi formula pupuk hayati berbahan aktif pseudomonad fluorescent isolat Pf-122 untuk meningkatkan pertumbuhan dan produksi tanaman cabai di lapang. Untuk beberapa agens pengendali biologi tanaman, suatu formulasi yang efisien diperlukan untuk aplikasi dalam skala besar di lapang. Tujuan penelitian untuk mengkaji beberapa formulasi pupuk hayati berbahan aktif pseudomonad fluoresent isolat Pf-122 dalam memacu pertumbuhan dan produksi cabai pada skala lapang. Penelitian menggunakan Rancangan Acak Kelompok (RAK) yang terdiri dari 3 macam formulasi yaitu serbuk, granul dan pelet. Sebagai kontrol tanaman cabai tanpa pemberian formula. Hasil penelitian menunjukkan bahwa pertumbuhan dan produksi cabai baik tinggi tanaman, jumlah cabang, jumlah cabang produktif, jumlah buah dan berat buah pada tanaman yang diperlakukan dengan formulasi serbuk paling baik dibandingkan pada kontrol dan formulasi yang lain. Untuk hasil jumlah buah, pemberian formulasi serbuk dapat mencapai dua kali hasil pada kontrol bahkan untuk berat buah dapat mencapai lebih dari empat kali lebih tinggi dari pada kontrol. Pada peubah pertumbuhan dan produksi tanaman cabai pemberian formulasi granul dan pelet tidak berbeda nyata hasilnya. Dengan demikian introduksi formulasi serbuk berbahan aktif pseudomonad fluorescent isolat Pf-122 adalah yang paling baik dalam memacu pertumbuhan dan produksi cabai di lapang.

Kata kunci: granul, pelet, pseudomonad fluorescent, serbuk

\section{PENDAHULUAN}

Salah satu jenis sayuran buah yang memiliki potensi untuk dikembangkan karena cukup penting peranannya baik untuk memenuhi kebutuhan konsumsi nasional maupun komoditas ekspor adalah cabai merah (Capsicum annuum L.). Produktivitas cabai di Indonesia saat ini masih tergolong rendah. Faktor-faktor yang menyebabkan rendahnya produksi antara lain penggunaan benih yang kurang bermutu, teknik budidaya yang belum efisien dan penanaman kultivar cabai yang tidak tahan terhadap hama serta penyakit (Soelaiman \& Ernawati, 2013). Untuk mengatasi masalah penyakit cabai ini, pada umumnya petani melakukan pengendalian secara konvensional, yaitu dengan menggunakan pestisida secara intensif. 
Penggunaan pestisida ini bahkan mencapai $51 \%$ dari biaya produksi. Dari jumlah tersebut, $17,6 \%$ digunakan untuk mengatasi penyakit tanaman, dan sisanya untuk penggunaan insektisida (Anonim, 2009). Upaya lain untuk mengatasi penyakit tanaman yang tidak kalah penting adalah meningkatkan ketahanan dan pertumbuhan cabai.

Rhizobacteria atau bakteri rizosfer banyak yang mempunyai prospek dan potensi pengimbas pertumbuhan tanaman. Bakteri rizosfer ada yang bersifat saprofitik dan bersifat parasit. Beberapa bakteri saprofitik sebagai agens hayati pengendali penyakit layu antara lain adalah bakteri Pseudomonas fluorescens pada tomat, kentang, dan terung, serta Pseudomonas sp. pada cabai (Saddler, 2005). Pengendalian hayati patogen tanaman dengan rhizobakteria dapat didasarkan pada produksi metabolit bakteri seperti siderofor, antibiotik, dan hydrogen cyanida. Rhizobakteria juga mampu memacu pertumbuhan tanaman dengan memproduksi zat pengatur tumbuh seperti turunan auxin (Pinton et al., 2001). Sebagian besar rhizobakteria seperti Pseudomonas, Bacillus, Azotobacter memproduksi senyawa pemacu pertumbuhan seperti Indolacetic acid (IAA), gibberellin, substansi seperti cytokinin (Brimecombe et al., 2001). Bakteri mampu memacu ketahanan sistemik dengan memproduksi fitohormon, melarutkan fosfat anorganik, meningkatkan pengikatan Fe dengan siderofor (Podile \& Kishore, 2007; Haas \& Defago, 2005).

Mekanisme lain dari rhizobacteria atau bakteri rizosfer dalam meningkatkan pertumbuhan tanaman adalah sebagai penyedia fosfat bagi tanaman. Oleh karena itu salah satu cara untuk memperbaiki defisiensi fosfat pada tanaman adalah dengan inokulasi tanah dengan mikroorganisme pelarut fosfat. Salah satu bakteri yang merupakan pelarut potensial dari fosfat adalah Pseudomonas dan Bacillus (Beattie, 2007).

Hasil penelitian Wuryandari et al. (2013) menunjukkan bahwa isolat pseudomonad fluoresent Pf122 mampu meningkatkan pertumbuhan dan produksi tanaman cabai pada skala lapang. Peningkatan jumlah buah maupun berat buah cabai sangat tinggi sampai lebih dari 4 kali dibandingkan kontrol atau tanpa pemberian pseudomonad fluoresent Pf-122. Aplikasi pseudomonad fluoresent Pf-122 pada tanaman cabai adalah dengan pencelupan bibit cabai.

Untuk beberapa agens pengendali biologi tanaman, suatu formulasi yang efisien diperlukan untuk aplikasi dalam skala besar di lapangan. Pabrik mini yang dimiliki UPN Veteran Jawa Timur telah memproduksi secara rutin beberapa pupuk organik. Produksi pupuk belum optimal sehingga perlu dilakukan upaya untuk mengembangkan dan meningkatkan produksinya sehingga kualitas dan kuantitasnya semakin meningkat. Untuk itu perlu memberi nilai tambah pupuk organik yaitu dengan menambah atau menyisipkan bahan aktif rhizobakteria pseudomonad fluoresent isolat Pf-122. Pupuk organik yang telah ditambah rhizobakteria pseudomonad fluoresent isolat Pf-122 diharapkan selain mampu bertahan dari penyakit juga lebih menginduksi dan meningkatkan produksi tanaman. Oleh karena itu dilakukan pengembangan produk pupuk menjadi formula dengan bahan aktif pseudomonad fluoresent isolat Pf-122 yang mampu memacu pertumbuhan dan produksi tanaman cabai. Tujuan penelitian ini adalah untuk mendapatkan formulasi pupuk hayati dengan bahan aktif pseudomonad fluoresent isolat Pf-122 yang paling baik dalam meningkatkan pertumbuhan dan produksi cabai.

\section{METODE PENELITIAN}

Tempat dan Waktu. Penelitian dilakukan di lahan pertanaman cabai di Desa Lebo, Kecamatan Sukodono, kabupaten Sidoarjo, Jawa Timur. Penelitian dilakukan pada bulan Mei sampai Juli 2015.

Rancangan Penelitian. Penelitian menggunakan Rancangan Acak Kelompok (RAK) yang terdiri dari 3 perlakuan yaitu serbuk, pelet, dan granul. Bentuk formula tersebut dibuat dengan bahan aktif bakteri pseudomonad fluorescent isolat Pf-122. Setiap perlakuan terdapat 3 ulangan.

Formula dibuat dengan mengkombinasikan bahan pembawa berupa pupuk organik produk Pabrik Mini UPN Veteran Jawa Timur, dan inokulum rhizobakteria pseudomonad fluorescent isolat Pf-122. Komposisi pupuk organik yang digunakan mengacu pada Wuryandari et al. (2015) yaitu dengan bahan pembawa formulasi antara lain blotong, kotoran sapi, kandarwati, dan guano dengan masing-masing perbandingan $3 \mathrm{~kg}$ : $1 \mathrm{~kg}: 3 / 4 \mathrm{~kg}: 1 / 2 \mathrm{~kg}$. Semua bahan selanjutnya dicampur dengan $120 \mathrm{ml}$ pseudomonad fluorescent isolat Pf-122 konsentrasi $10^{10} \mathrm{CFU} / \mathrm{ml}$. Semua bahan dimasukkan pada alat pembuat pupuk sehingga campuran yang terbentuk berupa beberapa formula yaitu serbuk, granul, dan pelet.

Tahapan uji yang dilakukan untuk mengetahui pengaruh formula pseudomonad fluorescent terhadap pertumbuhan dan produksi tanaman cabai adalah sebagai berikut; a). Bibit cabai yang berumur 30 hari dipindahkan ke lapang yang telah diberi formula sebanyak $10 \mathrm{~g}$ per lubang tanam, b). Pemberian formula yang kedua, diberikan pada umur 8 minggu yaitu pada saat tanaman 
belum membentuk fase generatif atau pembungaan, c). Inokulasi bakteri patogen Ralstonia solanacearum dan Fusarium oxysporum dilakukan secara alami atau tidak dilakukan inokulasi $R$. solanacearum dan $F$. oxysporum secara buatan.

Keefektifan formula pupuk hayati dalam memacu pertumbuhan dan produksi tanaman cabai akan ditentukan dengan mengamati: 1 ). Indeks penyakit layu pada tanaman cabai, 2). Pertumbuhan tanaman cabai meliputi tinggi tanaman, jumlah cabang, dan jumlah cabang produktif, 3). Produksi cabai meliputi jumlah buah dan berat buah.

Pengamatan perkembangan penyakit atau indeks penyakit dilakukan setiap 5 hari sampai hari ke-30. Besarnya indeks penyakit dihitung dengan rumus (Arwiyanto, 1995):

$$
I=\frac{\sum_{i=0}^{k} k \cdot n k}{Z \times N} \times 100 \%
$$

dengan:

$$
\begin{array}{ll}
\mathrm{I} & =\text { indeks penyakit } \\
\mathrm{nk} & =\text { jumlah tanaman yang bergejala sakit } \\
& \quad \text { dengan skala } \mathrm{k}(0,1,2,3,4,5) \\
\mathrm{N} & =\text { jumlah total tanaman yang diinokulasi } \\
\mathrm{Z} & =\text { kategori serangan tertinggi }
\end{array}
$$

Berat serangan dihitung menurut skala sebagai berikut: skor $0=$ tidak terdapat gejala

skor $1=$ terdapat daun layu $1-10 \%$

skor $2=$ terdapat daun layu $11-30 \%$

skor $3=$ terdapat daun layu $31-60 \%$

skor $4=$ terdapat daun layu $61-99 \%$

skor $5=$ terdapat daun layu $100 \%$

Semua data yang diperoleh dianalisis dengan analisis varian (Anova). Uji lanjut dengan BNT pada taraf kepercayaan 5\%. Untuk besarnya penekanan perkembangan penyakit dihitung dari Indeks penyakit kontrol dikurangi Indeks penyakit pada perlakuan.

\section{HASIL DAN PEMBAHASAN}

Indeks Penyakit. Selain pertumbuhan dan produksi tanaman, untuk mengetahui pengaruh perlakuan pemberian formula terhadap tanaman cabai maka dilakukan pengamatan terhadap indeks penyakit layu pada cabai. Pada pengamatan hari ke-30 setelah perlakuan, indeks penyakit pada kontrol paling tingi yaitu $55,96 \%$. Adapun indeks penyakit pada tanaman cabai yang diberi formula serbuk menunjukkan paling rendah, yaitu $13,23 \%$ kemudian diikuti formula granul dan formula pelet yaitu $21,43 \%$ dan $28,10 \%$ (Tabel 1). Nilai Indeks penyakit layu di lahan penelitian di bawah $75 \%$, Hal ini menunjukkan bahwa penyakit layu di lahan Kelurahan Lebo masih kategori sedang, namun demikian tetap patut diwaspadai serangannya karena sudah diatas $50 \%$.

Apabila dibandingkan dengan kontrol, maka formula serbuk mampu menekan perkembangan penyakit sebesar $42,73 \%$ sedangkan dengan granul dan pelet hanya mampu menekan perkembangan penyakit sebesar $34,53 \%$ dan $27,86 \%$. Hal tersebut membuktikan bahwa pemberian formula serbuk sangat berperan dalam menekan penyakit layu yang disebabkan oleh $F$. oxysporum dan $R$. solanacearum. Adanya agens hayati pseudomonad fluorescent isolat Pf-122 dalam formula berperan menekan perkembangan patogen penyebab layu. Pada formula serbuk, populasi pseudomonad fluorescent isolat Pf-122 mungkin cukup berkembang dengan lebih baik dibandingkan pada formula yang lain. Bakteri pseudomonad fluorescent isolat Pf-122 dalam formula serbuk langsung dapat menyatu dengan tanah atau lahan sehingga populasinya dapat berkembang lebih cepat. Selain itu diduga dalam formula serbuk pseudomonad fluorescent isolat Pf-122 lebih dapat

Tabel 1. Indeks penyakit layu tanaman cabai dengan perlakuan formula berbahan aktif pseudomonad fluorescent isolat Pf-122

\begin{tabular}{cc}
\hline Formula & Indeks penyakit hari ke 30 \\
\hline Serbuk & $13,23 \mathrm{a}$ \\
Granul & $21,43 \mathrm{~b}$ \\
Pelet & $28,10 \mathrm{c}$ \\
Kontrol & $55,96 \mathrm{~d}$ \\
\hline
\end{tabular}

Angka-angka yang diikuti huruf yang berbeda dalam satu kolom menunjukkan tidak berbeda nyata berdasarkan uji BNT taraf $5 \%$. 
berkembang karena porositasnya lebih tinggi, tidak seperti formula pelet dan granul, sehingga kebutuhan oksigen tercukupi. Hal tersebut seperti pendapat Palleroni (1984), bahwa bakteri Pseudomonas fluorescens termasuk bakteri obligat aerob.

Adanya populasi pseudomonad fluoresent isolat Pf-122 yang tinggi pada daerah perakaran akan lebih dapat menekan populasi patogen penyebab penyakit layu. Hal tersebut mungkin karena pseudomonad fluorescent isolat Pf-122 dapat menghasilkan senyawa yang dapat menghambat patogen. Bakteri genus Pseudomonas juga memproduksi senyawa antimikroba atau senyawa penghambat seperti phenazine, pyrrolnitrin, pyluteorin, phloroglucinols, cyclic lipopeptides, dan hydrogen cyanida (Haas \& Defago, 2005). Selain itu mungkin dengan adanya pseudomonad fluorescent isolat Pf-122 akan dapat memacu pertumbuhan tanaman sehingga meningkatkan ketahanan tanaman cabai terhadap serangan patogen layu. Keberadaan pseudomonad fluorescent yang cukup pada daerah perakaran diduga dapat melarutkan fosfat memegang peranan dalam memperbaiki tanaman. Salah satu bakteri yang merupakan pelarut potensial dari fosfat adalah Pseudomonas dan Bacillus. Beberapa bakteri saprofitik yang berperan sebagai agens hayati pengendali penyakit layu adalah bakteri Pseudomonas fluorescens pada tomat, kentang, dan terung, dan Pseudomonas sp. pada cabai (Saddler, 2005).

Pertumbuhan Tanaman Cabai. Untuk pengamatan pertumbuhan tanaman cabai dibedakan menjadi 2 fase yaitu pada fase vegetatif dan fase generatif. Parameter pada fase vegetatif meliputi tinggi tanaman dan jumlah cabang. Adapun pengamatan pertumbuhan pada fase generatif meliputi jumlah cabang produktif. Apabila ditinjau dari pertumbuhan tanaman cabai pada fase vegetatif, baik pertumbuhan tinggi tanaman maupun jumlah cabang pemberian formula serbuk menunjukkan hasil yang paling tinggi dibandingkan formula lain dan kontrol (Tabel 2). Adapun perlakuan dengan pemberian formula pelet dan granul, keduanya tidak berbeda nyata pada pertumbuhan tinggi tanaman maupun jumlah cabang. Namun demikian pemberian formula granul dan pelet masih menunjukkan jumlah cabang yang lebih tinggi dan berbeda nyata dengan kontrol.

Pertumbuhan tanaman cabai pada fase generatif yaitu jumlah cabang produktif, dengan pemberian formula serbuk menunjukkan hasil yang paling baik dibandingkan formula lain dan kontrol. Aplikasi formula granul dan pelet tidak berbeda dalam pertumbuhan jumlah cabang produktif, tetapi masih berbeda nyata dibandingkan kontrol (Tabel 2).

Dengan pemberian formula serbuk berbahan aktif pseudomonad fluorescent isolat Pf-122, pertumbuhan tanaman cabai menunjukkan hasil tertinggi, mungkin karena populasi bakteri pseudomonad fluorescent isolat Pf-122 dalam tanah lebih tinggi dibandingkan dengan pemberian formula yang lain. Bakteri pseudomonad fluorescent isolat Pf-122 dalam formula serbuk lebih cepat tercampur dengan tanah sehingga bakteri cepat berkembang dan mengkolonisasi sistem perakaran. Pada akar, pseudomonad fluorescent isolat Pf-122 diduga akan membantu pengikatan fosfor bagi tanaman, sehingga pertumbuhan akan semakin terpacu. Selain itu kemungkinan rhizobakteria pseudomonad fluorescent isolat Pf-122 menghasilkan hormon pertumbuhan yang memacu pertumbuhan tanaman cabai. Hal tersebut seperti pendapat Podile \& Kishore (2007), bakteri mampu memacu ketahanan sistemik dengan memproduksi fitohormon, melarutkan fosfat anorganik, dan meningkatkan pengikatan $\mathrm{Fe}$ dengan siderofor. Pengendalian hayati dengan mikroorganisme yang bermanfaat akan memacu pertumbuhan akar sehingga akar menjadi lebih banyak. Mikroorganisme tanah yang dapat melarutkan fosfat memegang peranan dalam memperbaiki tanaman.

Tabel 2. Rata-rata tinggi tanaman, jumlah cabang, dan jumlah cabang produktif tanaman cabai yang diperlakukan dengan 3 formulasi berbeda berbahan aktif pseudomonad fluorescent isolat Pf-122

\begin{tabular}{lccc}
\hline \multicolumn{1}{c}{ Formula } & Tinggi tanaman $(\mathrm{cm})$ & Jumlah cabang & Jumlah cabang produktif \\
\hline Serbuk & $59,47 \mathrm{~b}$ & $21,80 \mathrm{c}$ & $9,67 \mathrm{c}$ \\
Granul & $51,20 \mathrm{a}$ & $18,73 \mathrm{~b}$ & $6,53 \mathrm{~b}$ \\
Pelet & $47,93 \mathrm{a}$ & $19,07 \mathrm{~b}$ & $6,47 \mathrm{~b}$ \\
Kontrol & $47,93 \mathrm{a}$ & $17,67 \mathrm{a}$ & $5,00 \mathrm{a}$ \\
\hline
\end{tabular}

Angka-angka yang diikuti huruf yang berbeda dalam kolom yang sama menunjukkan tidak berbeda nyata berdasarkan uji BNT taraf 5\%. 
Mikroorganisme tanah juga mungkin membebaskan fosfat anorganik yang dapat larut ke dalam tanah. Salah satu cara untuk memperbaiki defisiensi fosfor pada tanaman adalah dengan inokulasi tanah dengan mikroorganisme pelarut fosfat. Salah satu bakteri yang merupakan pelarut potensial dari fosfat adalah Pseudomonas (Rao, 1994). Banyak genus bakteri, salah satu diantaranya adalah Pseudomonas, menghasilkan suatu senyawa giberelin dan yang serupa giberelin yang dapat merangsang pertumbuhan tanaman. Bakteri ini juga mempengaruhi perkembangan rambut akar, sekresi getah, perkembangan akar lateral tanaman.

Produksi Tanaman Cabai. Untuk pengamatan terhadap produksi tanaman cabai, parameter yang diamati meliputi jumlah buah dan berat buah. Apabila ditinjau dari produksi tanaman cabai baik jumlah buah maupun berat buah, pemberian formula serbuk dengan bahan aktif pseudomonad fluorescens Pf-122 menunjukkan hasil yang paling tinggi dibandingkan formula lain dan kontrol (Tabel 3).

Apabila ditinjau dari jumlah buah, pemberian formula serbuk dapat meningkatkan hasil sampai dua kali hasil dari tanaman kontrol. Sedangkan untuk hasil berat buah, pemberian formula serbuk dapat meningkatkan hasil sampai empat kali dari tanaman kontrol. Untuk pemberian formula pelet dan granul, nampak bahwa hasil jumlah buah dan berat buah juga berbeda nyata dibandingkan kontrol. Adanya peningkatan hasil produksi cabai pada tanaman cabai yang diberi formula menunjukkan adanya pengaruh baik dari bakteri pseudomonad fluorescent isolat Pf-122. Adanya populasi di dalam sistem perakaran akibat aplikasi formula, kemungkinan mengkolonisasi akar tanaman cabai dan dapat melarutkan fosfat yang dibutuhkan tanaman atau menghasilkan hormon pertumbuhan sehingga dapat memacu pertumbuhan tanaman cabai.

Pemberian formula serbuk dibandingkan dengan formula granul, dan pelet baik dari rata-rata jumlah buah dan berat buah menunjukkan nilai yang paling baik, kemudian diikuti formula granul dan pelet. Hal tersebut mungkin disebabkan karena populasi pseudomonad fluorescent isolat Pf-122 lebih cepat berkembang dalam formula serbuk dibandingkan dengan dalam formula granul dan pelet. Kondisi formula serbuk yang lebih poros memungkinkan lebih banyak oksigen yang dapat diperoleh bakteri pseudomonad fluorescent isolat Pf122, sehingga populasi lebih banyak. Sedangkan untuk formula pelet, kondisi formula paling padat, sehingga hal tersebut akan dapat mempengaruhi viabilitas bakteri karena sangat sedikit mendapatkan oksigen. Selain hal tersebut di atas, formula pelet paling lama terdegradasi atau tercampur dengan tanah di daerah perakaran dibandingkan granul dan serbuk, sehingga akan mempengaruhi bakteri dalam mengkolonisasi sistem perakaran dan membantu melarutkan fosfat untuk pertumbuhan tanaman cabai.

Adanya pseudomonad fluorescens mungkin juga dapat memacu pertumbuhan dan produksi tanaman cabai karena produksi hormon pertumbuhan yang dihasilkan. Hal itu sesuai dengan pendapat Pinton et al. (2001), rhizobakteria juga mampu memacu pertumbuhan tanaman dengan memproduksi zat pengatur tumbuh seperti turunan auxin. Banyak genus bakteri, salah satu diantaranya adalah Pseudomonas, menghasilkan suatu senyawa giberelin dan yang serupa giberelin yang dapat merangsang pertumbuhan tanaman. Bakteri ini juga mempengaruhi perkembangan rambut akar, sekresi getah, perkembangan akar lateral tanaman. Sebagian besar rhizobakteria seperti Pseudomonas, Bacillus, Azotobacter memproduksi senyawa pemacu pertumbuhan seperti Indolacetic acid (IAA), gibberellin, substansi seperti cytokinin (Brimecombe et al., 2001). Bakteri mampu memacu ketahanan sistemik tanaman dengan memproduksi fitohormon, melarutkan fosfat anorganik, dan meningkatkan pengikatan Fe dengan siderofor (Haas \& Defago, 2005).

Dibandingkan hasil perlakuan dengan formula pelet dan granul, formula serbuk memberikan hasil yang terbaik. Hal tersebut diduga pada saat diaplikasikan ke

Tabel 3. Rata-rata jumlah buah dan berat buah cabai yang diperlakukan dengan formula pseudomonad fluorescent isolat Pf-122

\begin{tabular}{lcc}
\hline \multicolumn{1}{c}{ Formula } & Jumlah buah & Berat buah $(\mathrm{g})$ \\
\hline Serbuk & $69,47 \mathrm{~d}$ & $675,56 \mathrm{~d}$ \\
Granul & $43,93 \mathrm{~b}$ & $300,31 \mathrm{~b}$ \\
Pelet & $51,00 \mathrm{c}$ & $379,36 \mathrm{c}$ \\
Kontrol & $30,27 \mathrm{a}$ & $150,77 \mathrm{a}$ \\
\hline
\end{tabular}

Angka-angka yang diikuti huruf yang berbeda pada kolom yang sama menunjukkan tidak berbeda nyata berdasarkan uji BNT taraf $5 \%$. 
dalam lubang tugal, formula serbuk lebih cepat tercampur ke dalam tanah dekat sistem perakaran, sehingga pseudomonad fluorescent isolat Pf-122 lebih cepat berkembang biak dan mengkolonisasi pada system perakaran. Selain itu dalam formula serbuk bakteri pseudomonad fluorescent isolat Pf-122 lebih dapat berkembang karena kondisi tidak padat seperti formula pelet dan granul, sehingga kebutuhan oksigen tercukupi dan populasi bakteri lebih tinggi. Menurut Palleroni (1984), bakteri Pseudomonas fluorescens termasuk bakteri obligat aerob. Populasi pseudomonad fluorescent dalam tanah yang tinggi selanjutnya dapat membebaskan fosfat anorganik yang dapat larut ke dalam tanah, sehingga dapat memacu pertumbuhan dan produksi tanaman cabai.

\section{SIMPULAN}

Introduksi formula berbahan aktif pseudomonad fluorescent isolat Pf-122 dalam bentuk serbuk memberi hasil yang paling baik dalam memacu pertumbuhan dan produksi cabai di lapang.

\section{SANWACANA}

Penelitian ini dapat terlaksana atas biaya Hibah Penelitian Unggulan Perguruan Tinggi Nasional No. 079/SP2H/PL/Dit.Litabmas/II/2015, untuk itu kami ucapkan terima kasih kepada Direktur Penelitian dan Pengabdian kepada Masyarakat, Direktorat Jenderal Pendidikan Tinggi, Kementerian Pendidikan dan Kebudayaan Republik Indonesia.

\section{DAFTAR PUSTAKA}

Anonim. 2009. Budidaya Cabai Merah Keriting di Lahan Kering. http://www.mojokertokota.go.id. Diakses 2014.

Arwiyanto T. 1995. Strategi pengendalian penyakit layu bakteri tembakau cerutu di Sumatera Utara secara terpadu. Ekspose Hasil Penelitian Tembakau Deli IV. Medan.

Beattie GA. 2007. Survey, molecular phylogenygenomics and recent advances. In: Gnanamanickam SS (Ed.). Plant-Associated Bacteria. pp. 1-56. Springer, The Netherlands.

Brimecombe MJ, De Leij FA, \& Lynch JM. 2001. The effect of root exudates on rhizosphere microbiae populations. In: Pinton R, Varanini Z, \& Nanipieri $\mathrm{P}$ (Eds.). The Rhizophere. Biochemistry and
Organic Substances at the Soil-Plant Interface. pp. 95-140. Marcel Dekker, Inc. New York-Basel.

Haas D \& Defago G. 2005. Biological control of soil borne pathogens by fluorescent pseudomonads. Nat. Rev. Microbial. 3: 307-319.

Palleroni NJ. 1984. Pseudomonadaceae. Bergey's Manual of Systematic Bacteriology. In: Krieg NR \& Holt JG (Eds.). pp. 141-199. The Williams and Wilkins Co., Baltimore.

Pinton R, Varanini Z, \& Nanipieri P. 2001. The rhizophere as a site of biochemical interactions among soil components, plants, and microorganisms. In: Pinton R, Varanini Z, \& Nanipieri P (Eds.). The Rhizophere. Biochemistry and Organic Substances at the Soil-Plant Interface. pp.118. Marcel Dekker. New York-Basel.

Podile AR \& Kishore GK. 2007. Plant GrowthPromoting Rhizobacteria. In: Gnanamanickam SS. (Ed.). Plant-Associated Bacteria. pp. 195230. Springer. The Netherlands.

Rao SNS. 1994. Mikroorganisme Tanah dan Pertumbuhan Tanaman (Edisi kedua). Universitas Indonesia Press. Jakarta.

Saddler GS. 2005. Management of Bacterial Wilt Disease. In: Allen C, Prior P, \& Hayward AC (Eds.). Bacterial Wilt Disease and the Ralstonia solanacearum Species Complex. pp. 121-132. The American Phytopathological Society Press. America.

Soelaiman V \& Ernawati A. 2013. Pertumbuhan dan perkembangan cabai keriting (Capsicum annuum L.) secara in vitro pada beberapa konsentrasi BAP dan IAA. Bul. Agrohorti 1: 6266.

Wuryandari Y, Wiyatiningsih S, \& Sulistyono A. 2013. Kajian Introduksi Rhizobacteria pseudomonad fluorescens terhadap Pertumbuhan dan Produksi Cabai di Lapang. Prosiding Seminar Nasional Pengembangan Luaran Penelitian Mendukung Dunia Industri. pp. 37-43. 10-11 Desember 2013. LPPM UPN "Veteran" Jawa Timur.

Wuryandari Y, Wiyatiningsih S, \& Maroeto. 2015. Formula berbahan aktif pseudomonad fluoresen dan pengaruhnya terhadap perkembangan penyakit layu pada cabai. J. HPT Tropika 15(1): 89-94. 